\begin{tabular}{c|c|c}
\hline \hline Vol. 263: 29-42, 2003 & MARINE ECOLOGY PROGRESS SERIES \\
Mar Ecol Prog Ser & Published November 28 \\
\hline
\end{tabular}

\title{
Safety factors and nutrient uptake by seaweeds
}

\author{
T. Alwyn V. Rees* \\ Leigh Marine Laboratory, University of Auckland, PO Box 349, Warkworth, New Zealand
}

\begin{abstract}
The differences in the kinetic characteristics of nutrient (nitrate, ammonium and phosphate) uptake by seaweeds are evaluated using published half-saturation constants $\left(K_{\mathrm{m}}\right)$, maximum rates of uptake $\left(V_{\max }\right)$ and calculated safety factors for nitrate, ammonium and phosphate uptake. The safety factor is the ratio of maximum nutrient uptake rate to uptake rate at maximum ambient concentration of nutrient and provides a simple estimate of the amount of surplus capacity of a nutrient uptake system. Frequency distributions of $K_{\mathrm{m}}$ values for nitrate, ammonium and phosphate uptake show similar patterns, though values tend to be lower for phosphate uptake and greater for ammonium uptake. There is no relationship between the $K_{\mathrm{m}}$ values for nitrate or ammonium uptake and seaweed surface area:volume ratio (SA: $V$ ). Frequency distributions of $V_{\mathrm{max}}: K_{\mathrm{m}}$ values for nitrate, ammonium and phosphate uptake show similar patterns, but $V_{\text {max }}: K_{\mathrm{m}}$ values tend to be lower for phosphate uptake and greater for ammonium uptake. Moreover, rates of nitrate uptake (at $5 \mu \mathrm{M}$ nitrate) are comparable to rates of ammonium uptake (at $1.5 \mu \mathrm{M}$ ammonium) at any value of seaweed $\mathrm{SA}: V$ ratio, i.e. the efficiency of ammonium uptake is greater. For nitrate and phosphate uptake by seaweeds and ammonium uptake by phytoplankton values for safety factors are low. In contrast, values for ammonium uptake by seaweeds are high. It is suggested that the reason for the high surplus capacity for ammonium uptake in seaweeds is a combination of the size of the plant and the spatially and temporally variable concentration of ammonium in the seawater that surrounds these plants.
\end{abstract}

KEY WORDS: Seaweed · Nutrient uptake · Safety factor - Scaling · Surface area:volume ratio Resale or republication not permitted without written consent of the publisher

\section{INTRODUCTION}

Seaweeds are important primary producers in shallow coastal and estuarine ecosystems. One indication of this importance is that seaweed biomass per unit area is about 400 times greater than that of phytoplankton in these ecosystems (Smith 1981). Moreover, intertidal seaweeds can be extremely productive, with annual production of dry matter per unit area on exposed shores in excess of rain forests or grasslands (Leigh et al. 1987). The relative amount of net primary production attributable to seaweeds or phytoplankton varies with location and may be almost exclusively pelagic or benthic (Borum \& Sand-Jensen 1996). In general, areal rates of net primary production are greater for seaweeds than phytoplankton, but globally, seaweeds are responsible for about $5 \%$ (Smith 1981) to $10 \%$ (CharpyRoubaud \& Sournia 1990) of marine primary production. This value increases to $37 \%$ for continental shelf waters (Charpy-Roubaud \& Sournia 1990) and, often, an even greater percentage in shallow coastal waters and estuaries (Borum \& Sand-Jensen 1996).

Clearly, seaweed-based ecosystems are potentially very productive. However, this productivity can only be sustained through the acquisition and utilization of nutrients, particularly nitrogen. In pristine coastal and estuarine waters the most abundant source of nitrogen is nitrate (Sharp 1983), but for many estuaries and coastal areas adjacent to human population centres there is evidence that nitrogen loading is increasing. About $37 \%$ of the world's population lives within $100 \mathrm{~km}$ of the coastline (Cohen et al. 1997). Consequently, it is hardly surprising that the input of anthropogenic nutrients into coastal waters has increased in recent times (Morand \& Briand 1996, Valiela et al. 1997, Schramm 1999). There are many instances of increased levels of nitrate (Cloern 2001) and ammonium (Campbell 2001, Barr \& Rees 2003). 
The rate of uptake of a given nutrient should be a function of the surface area presented by the seaweed per unit of its biomass, i.e. its surface area:volume (SA:V) ratio. In general, this scaling relationship has been observed (Rosenberg \& Ramus 1984, Hein et al. 1995), with increased rates of uptake per unit biomass for increasing SA: $V$ ratios. However, the relationships for ammonium uptake by seaweeds differ depending on the geographical region (Taylor et al. 1998). In addition, it has been suggested that for algae in general (phytoplankton and seaweeds) there is a negative relationship between $K_{\mathrm{m}}$ (the concentration of substrate that gives half the maximum rate of uptake) for nutrient uptake and SA:V ratio (Hein et al. 1995).

A major difference between phytoplankton and seaweeds is their protein content. Phytoplankton have a high protein content (about $50 \%$ dry weight) and a low $\mathrm{C}: \mathrm{N}$ ratio (Redfield ratio $=6.6$ ), whereas seaweeds generally have a lower (about $15 \%$ dry weight) protein content and a higher C:N ratio (about 20) (Atkinson \& Smith 1983, Duarte 1992). However, there are exceptions. For example, red algae may have a high protein content (up to $30 \%$ dry weight) (Rico \& Fernandez 1996) and a low C:N ratio (<9), particularly if their growth is light limited (Bird et al. 1981, Lapointe \& Duke 1984). In general, the mass-specific nitrogen demand of a seaweed will be lower than that for a phytoplankton cell. In addition to a lower protein content, the maximum growth rate of seaweeds is considerably lower than that of phytoplankton (Nielsen \& Sand-Jensen 1990). This translates into a lower demand for nitrogen per unit biomass. However, at an ecosystem level, there can be considerably more biomass of seaweed (Smith 1981) and the ecosystem nitrogen demand may be as great or greater for seaweeds than phytoplankton.

This demand for nutrients by seaweeds, together with the enhanced (largely anthropogenic) input of nutrients into coastal and estuarine waters suggest that an improved understanding of the characteristics of nutrient uptake by seaweeds is of central importance in understanding their contribution to nutrient utilization. Given that the major sources of nitrogen and phosphorus for seaweeds are nitrate, ammonium and phosphate, how much of their capacity to take up these nutrients is utilized by seaweeds in nature? Safety factors (Diamond 1998, 2002) provide a measure of the amount of surplus capacity that exists when a transporter or enzyme is utilizing the maximum ambient concentration of the substrate. It should be emphasized that this represents surplus capacity relative to the maximum concentration of the nutrient that a given seaweed is likely to encounter in nature. This is not the same as the extent to which a rate of uptake is surplus to the maximum growth rate (McCarthy \& Goldman
1979). Here, I review the available data on the kinetic characteristics of nutrient (nitrate, ammonium and phosphate) uptake by seaweeds and suggest that safety factors (the ratio of maximum nutrient uptake rate to uptake rate at maximum ambient concentration of nutrient) provide a simple estimate of the surplus capacity of nutrient uptake, which is markedly greater for ammonium uptake than either nitrate or phosphate uptake in seaweeds.

\section{METHODS}

I searched the literature for kinetic parameters for nitrate, ammonium and phosphate uptake and SA:V ratios for seaweeds. The 2 kinetic parameters derived from the hyperbolic relationship between nutrient concentration and rates of nutrient uptake are $K_{\mathrm{m}}$, which is the concentration of nutrient that gives half the maximum rate of uptake, and $V_{\max }$, which is the maximum rate of uptake achieved at saturating concentrations of the nutrient. It should be noted that values for SA:V ratios were usually obtained from different published sources to kinetic parameters. The data include both fast-growing, ephemeral species, with high SA: $V$ ratios (e.g. Enteromorpha intestinalis, Ulva lactuca), and slow-growing perennial species, with low SA:V ratios (e.g. Fucus vesiculosus, Xiphophora gladiata). When more than 1 value for $K_{\mathrm{m}}$ and $V_{\max }$ are given for a species from the same location, mean values were used. If the relationship between rate of uptake and concentration was linear, values for $K_{\mathrm{m}}$ were recorded as $>25 \mu \mathrm{M}$. In most instances each recorded value was for a single species or subspecies. However, data for the same species from different geographical regions were kept as separate values. These species (with the number of regions in parentheses) were for ammonium uptake Chaetomorpha linum (2), Ulva lactuca (3), Ceramium rubrum (2) and Fucus distichus (2); for nitrate uptake Chaetomorpha linum (2); and for phosphate uptake Fucus vesiculosus (2).

Seawater samples at Waterfall Reef, northeastern New Zealand $\left(36^{\circ} 55^{\prime} \mathrm{S}, 175^{\circ} 7^{\prime} \mathrm{E}\right)$, have been collected at weekly intervals since January 1995. These data allow safety factors to be calculated for nutrient uptake by seaweeds collected from the same site. Samples were frozen $\left(-18^{\circ} \mathrm{C}\right)$ unfiltered in acid-washed polycarbonate bottles. There was no significant difference in nutrient concentrations in filtered and unfiltered seawater (Barr \& Rees 2003). Nutrient (nitrate, ammonium and phosphate) concentrations were determined in triplicate. Nitrate was determined as described by Parsons et al. (1984), ammonium as described by Koroleff (1983b), and phosphate as described by Koroleff (1983a). 
Safety factors (Diamond 1998, 2002) provide a measure of the amount of surplus capacity that exists when a transporter or enzyme is utilizing the maximum available concentration of the substrate. For seaweed nutrient uptake, safety factors were calculated as:

$V_{\text {max }}$ for nutrient

rate of nutrient uptake at maximum ambient concentration of nutrient

Rates of nutrient uptake ( $\mu \mathrm{mol} \mathrm{g}^{-1}$ dry weight $\mathrm{h}^{-1}$ ) at defined concentrations (Table 1) were calculated from the Michaelis-Menten formula:

$V_{\max } \times$ maximum ambient concentration $K_{\mathrm{m}}+$ maximum ambient concentration

If $V_{\max }$ values were not available, safety factors were calculated from the $K_{\mathrm{m}}$ value as:

$$
\frac{K_{\mathrm{m}}+\text { maximum ambient concentration }}{\text { maximum ambient concentration }}
$$

For phytoplankton, only kinetic data for cultured, coastal clones were used. If both $K_{\mathrm{m}}$ and $V_{\max }$ values are available, the 2 formulae give identical values for the safety factor. If the relationship between rate of uptake and concentration was linear the safety factor is infinite and, for convenience, such values for safety factor were recorded as $>10$. Ideally, the safety factor for the uptake of a nutrient by any given seaweed should be calculated for the maximum concentrations of the nutrient that it normally encounters. Safety factors were calculated for seaweeds from the Baltic Sea and New Zealand based on maximum measured concentrations of these nutrients at the same sites that the seaweeds were collected (Table 1). In the absence of these data, I calculated safety factors based on maximum nitrate, ammonium and phosphate concentrations in coastal seawater of 5, 1.5 and $1 \mu \mathrm{M}$, respectively. These values were chosen based on measured maximum concentrations of these nutrients from 3 geographical regions (Baltic Sea, New Zealand and Nova Scotia) (Table 1). Data for seaweeds from these

Table 1. Maximum concentrations ( $\mu \mathrm{M})$ of nitrate, ammonium and phosphate in seawater from the Baltic Sea (Wallentinus 1984), Nova Scotia (Chapman \& Craigie 1977, Gagne et al. 1982, Probyn \& Chapman 1983), Brighton Beach, South Island, New Zealand (Brown et al. 1997, Phillips 2001), and Waterfall Reef, North Island, New Zealand. Only data for entire annual cycles are included. Where given, values are means \pm SE

\begin{tabular}{|lccc|}
\hline & Nitrate & Ammonium & Phosphate \\
\hline Baltic Sea & 5.43 & 0.83 & 0.78 \\
Nova Scotia & $5.50 \pm 0.99$ & $1.09 \pm 0.30$ & $0.77 \pm 0.09$ \\
Brighton Beach & 4.98 & 1.67 & 0.63 \\
Waterfall Reef & $4.69 \pm 0.59$ & $2.44 \pm 0.67$ & $2.19 \pm 0.87$ \\
\hline
\end{tabular}

regions provide 40,50 and $57 \%$ of the $K_{\mathrm{m}}$ and safety factor data for ammonium, nitrate and phosphate uptake that are used here.

The entire data set is given in Appendices 1 to 5 (available at www.int-res.com/journals/suppl/rees_ appendices.pdf). Reduced major axis (RMA) regression (Sokal \& Rohlf 1995) was used to describe relationships between $\mathrm{SA}: V$ ratio and uptake rates.

\section{RESULTS}

For nitrate uptake by seaweeds, most (70\%) of the $K_{\mathrm{m}}$ values were less than $10 \mu \mathrm{M}$ (Fig. 1). Similarly, $K_{\mathrm{m}}$ values for phosphate uptake were also low; $80 \%$ were

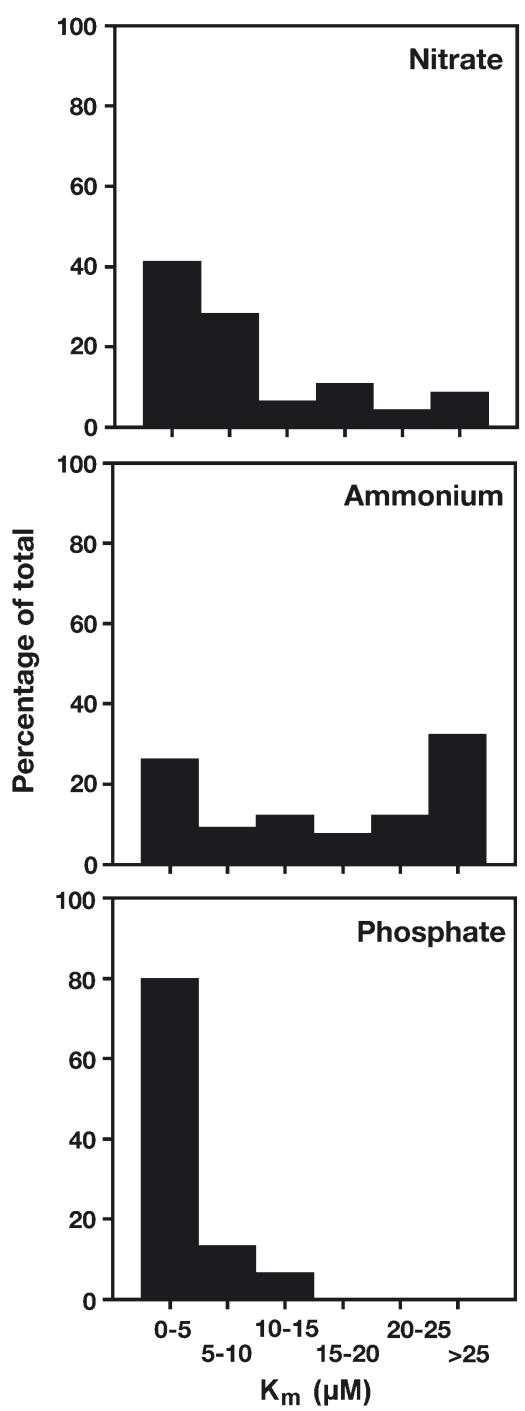

Fig. 1. Frequency distribution of $K_{\mathrm{m}}$ values for nitrate $(\mathrm{n}=46)$, ammonium $(\mathrm{n}=65)$ and phosphate $(\mathrm{n}=30)$ uptake by seaweeds 

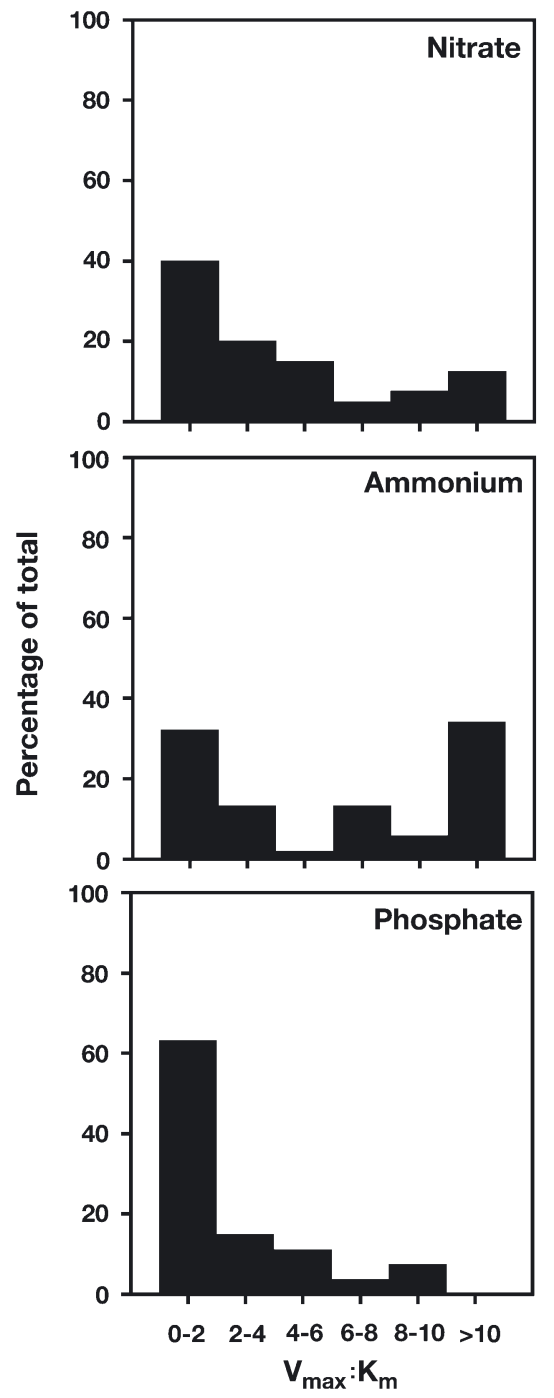

Fig. 2. Frequency distribution of $V_{\max }: K_{\mathrm{m}}$ for nitrate $(\mathrm{n}=40)$, ammonium $(\mathrm{n}=53)$ and phosphate $(\mathrm{n}=27)$ uptake by seaweeds

less than $5 \mu \mathrm{M}$ and $40 \%$ were $1 \mu \mathrm{M}$ or less. $K_{\mathrm{m}}$ values for ammonium uptake were, in general, higher than those for nitrate or phosphate, with $65 \%$ greater than $10 \mu \mathrm{M}$ (Fig. 1). There was no relationship between seaweed SA: $V$ and $K_{\mathrm{m}}$ for ammonium or nitrate uptake (nitrate $\mathrm{r}^{2}=0.035$; ammonium $\mathrm{r}^{2}=0.001$ ) (data not shown). The ratio $V_{\text {max }}: K_{\mathrm{m}}$ has been used as a measure of uptake capacities at low concentrations (Healey 1980, Duke et al. 1989). There was relatively little difference in the distribution of values for $V_{\text {max }}: K_{\mathrm{m}}$ for nitrate, ammonium and phosphate uptake (Fig. 2), because nitrate and phosphate uptake had low $K_{\mathrm{m}}$ and $V_{\text {max }}$ values and ammonium uptake had high $K_{\mathrm{m}}$ and $V_{\text {max }}$ values. However, $V_{\text {max }}: K_{\mathrm{m}}$ for ammonium uptake $($ median $=6.28)$ were greater than for nitrate $($ median $=$
3.10) and phosphate (median $=1.56$ ) uptake. Though there was a trend for higher values of $V_{\text {max }}: K_{\mathrm{m}}$ with increasing $\mathrm{SA}: V$ (data not shown), this was due to increased $V_{\text {max }}$ with increasing SA: $V$ and the invariant relationship between $K_{\mathrm{m}}$ and SA: $V$. However, of the 5 species of seaweeds (Chaetomorpha linum, Cladophora glomerata, Dictyosiphon foeniculaceus, Enteromorpha ahlneriana and E. prolifera) that exhibited high (>10) $V_{\text {max }}: K_{\mathrm{m}}$ values for nitrate and ammonium uptake, 4 are species that belong to genera that form nuisance blooms (Chaetomorpha, Cladophora, Enteromorpha) (Morand \& Briand 1996). The relationships between seaweed SA: $V$ and rates of uptake of nitrate at $5 \mu \mathrm{M}$ and ammonium uptake at $1.5 \mu \mathrm{M}$ were almost identical (Fig. 3).

Most safety factors for nitrate and phosphate were 4 or less (78 and $73 \%$ respectively) assuming maximum concentrations of 5 and $1 \mu \mathrm{M}$, respectively (Fig. 4). In contrast, only $18 \%$ of safety factors for ammonium uptake (assuming a maximum concentration of $1.5 \mu \mathrm{M})$ were this low and most (55\%) were in excess of 10. There was no relationship between seaweed SA: $V$ and safety factors for ammonium or nitrate uptake (nitrate $r^{2}=0.044$; ammonium $r^{2}=0.0015$ ) (data

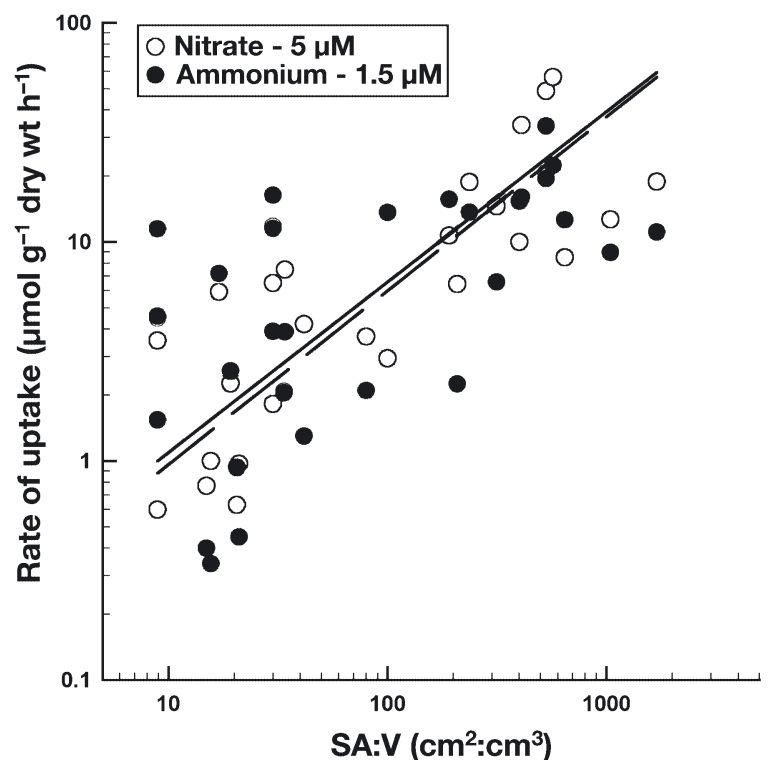

Fig. 3. Biomass-specific rates of nitrate (solid line) and ammonium (dashed line) uptake vs SA: $V$ ratio for seaweeds. Rates of nitrate uptake were calculated for $5 \mu \mathrm{M}$ nitrate and ammonium uptake for $1.5 \mu \mathrm{M}$ ammonium. Each data point corresponds to a single species or subspecies and only data where kinetics of both nitrate and ammonium uptake were available for the same species or subspecies at the same location were included. Reduced major axis regression equations and coefficients of determination are $y=0.18 x^{0.78}, r^{2}=0.61$, $\mathrm{p}($ slope $=0)<0.0001$ for nitrate uptake and $y^{\prime}=0.16 x^{0.79}$, $\mathrm{r}^{2}=0.38, \mathrm{p}($ slope $=0)=0.0004$ for ammonium uptake 

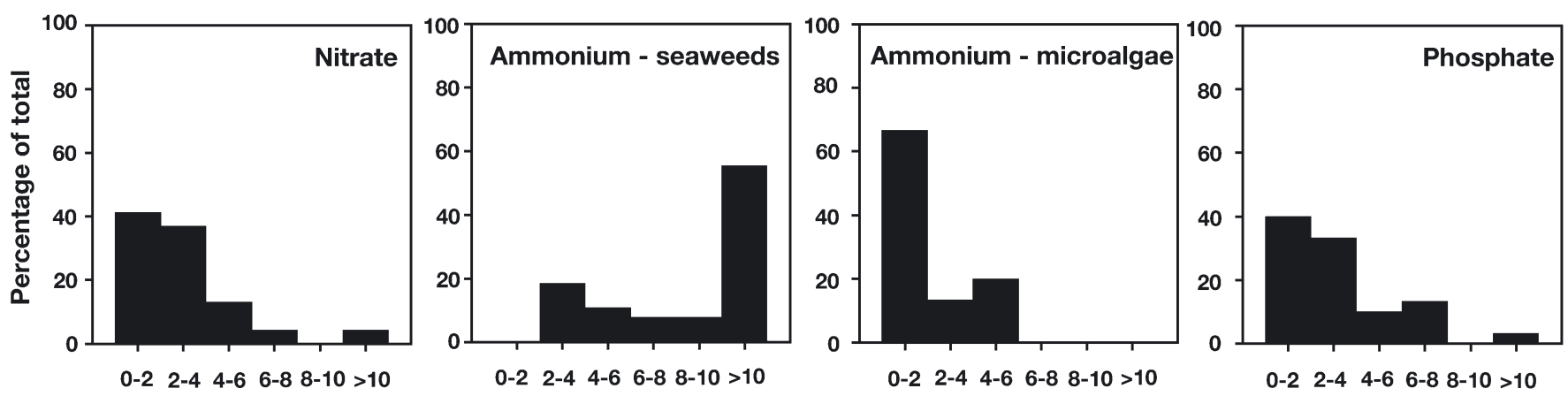

\section{Safety factor}

Fig. 4. Frequency distribution of safety factors for nitrate $(n=46)$, ammonium $(n=65)$ and phosphate $(n=30)$ uptake by seaweeds and ammonium uptake by coastal species of phytoplankton $(\mathrm{n}=15)$. Safety factors were calculated assuming maximum concentrations for nitrate, ammonium and phosphate of 5, 1.5 and $1 \mu \mathrm{M}$, respectively

not shown). Moreover, safety factors for ammonium uptake by coastal species of phytoplankton were similar to those for nitrate uptake by seaweeds (Fig. 4). A similar pattern was found when safety factors for seaweeds were calculated using maximum measured concentrations of nutrients. Safety factors for seaweeds from both the Baltic Sea and New Zealand had low values for nitrate uptake and high values for ammonium uptake (Fig. 5); Baltic seaweeds also had low safety factors for phosphate uptake (Fig. 5).

\section{DISCUSSION}

$K_{\mathrm{m}}$ values for nitrate and phosphate uptake by seaweeds are similar to the maximum concentrations of these nutrients encountered in coastal waters. The seasonal pattern of nitrate concentration in seawater is reasonably predictable, with high concentrations from late autumn to early spring, which decrease to nearly zero in late spring to early autumn. Moreover, at any given location, the maximum concentration of nitrate is
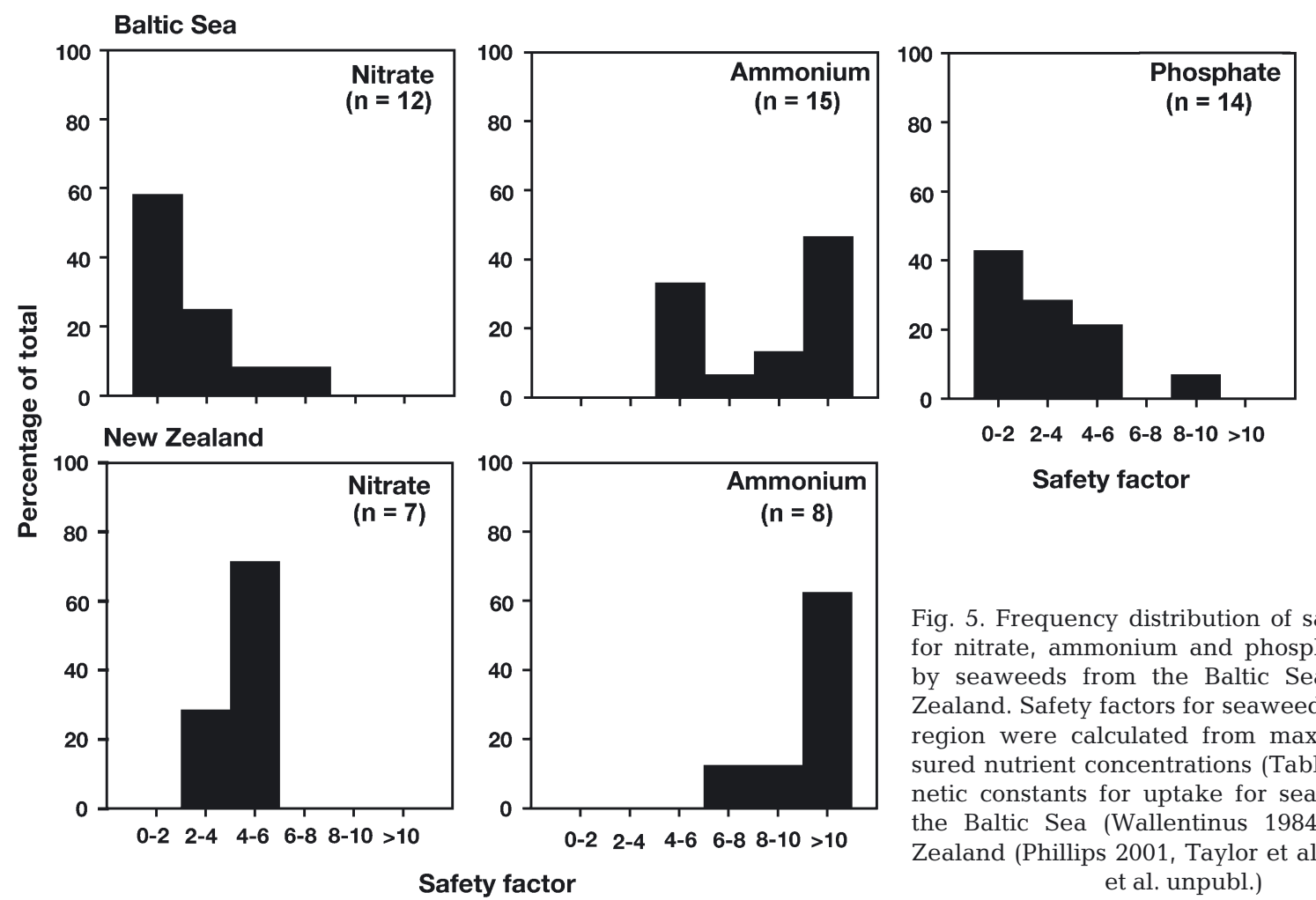

Fig. 5. Frequency distribution of safety factors for nitrate, ammonium and phosphate uptake by seaweeds from the Baltic Sea and New Zealand. Safety factors for seaweeds from each region were calculated from maximum measured nutrient concentrations (Table 1) and kinetic constants for uptake for seaweeds from the Baltic Sea (Wallentinus 1984) and New Zealand (Phillips 2001, Taylor et al. 1998, Rees et al. unpubl.) 
also reasonably predictable. The measured concentrations of nitrate in seawater are bulk concentrations, but it is unlikely that they vary greatly over the spatial scales that are likely to be of any consequence to a seaweed. This predictability and uniformity allows a low safety factor (i.e. uptake system operating close to the maximum rate). Phosphate is derived from mixing, sediments and excretion by animals and microorganisms, and, in general, is unlikely to limit growth of seaweeds in temperate silicalastic waters (Lapointe et al. 1992, Lobban \& Harrison 1994). Consequently, relative to the seaweed demand for phosphate to sustain growth, the ambient concentration of phosphate is stable and predictable. Moreover, in contrast to ammonium uptake, $K_{\mathrm{m}}$ values for phosphate uptake by coastal clones of marine phytoplankton (Cembella et al. 1984) are similar to those for seaweeds. However it should be noted that the availability of phosphate may limit seaweed growth at certain times of the year (e.g. O'Brien \& Wheeler 1987), and it is uncertain to what extent anthropogenic inputs into coastal waters have resulted in increased seawater phosphate concentrations. The latter would have caused a decrease in the safety factor for phosphate uptake (assuming no changes in the $K_{\mathrm{m}}$ for uptake) and the incidence of phosphate limitation of seaweed growth. If, in the past, concentrations of phosphate in coastal seawater were substantially lower than current levels, the supply of phosphate would presumably have been more unpredictable and seaweeds would have been at a selective advantage if they possessed high safety factors for phosphate uptake. Seaweeds from carbonate-rich tropical waters are limited by the availability of phosphate (Lapointe et al. 1992). The only available data for such seaweeds is for Sargassum baccularia and the $K_{\mathrm{m}}$ for phosphate uptake is very low compared to other seaweeds (Schaffelke \& Klumpp 1998). However, measured concentrations of phosphate in the coastal waters (Great Barrier Reef) where this seaweed occurs are generally at or below the detection limit (Schaffelke \& Klumpp 1998). Assuming a detection limit of $30 \mathrm{nM}$, the safety factor for phosphate uptake by $S$. baccularia would be a high value of 9.7 . With a safety factor of about 2 or less, the relationship between the rate of uptake and nutrient concentration is approaching zero-order. The effect of this on nitrate uptake is that increasing the ambient nitrate concentration from 5 to $10 \mu \mathrm{M}$ results in only a median $37 \%$ (range $=6$ to $100 \%$ ) increase in the rate of uptake. For phosphate uptake, increasing the ambient phosphate from 1 to $2 \mu \mathrm{M}$ results in a median $38 \%$ (range $=12$ to $84 \%$ ) increase in the rate of uptake.

The most likely explanation for the relatively high $K_{\mathrm{m}}$ values and safety factors for ammonium uptake by seaweeds is that uptake is dominated by a trans- porter(s) with a low affinity and high capacity. However, despite relatively high $K_{\mathrm{m}}$ values for ammonium uptake, the high uptake capacity allows seaweeds to take up the nutrient at about the same rate as nitrate, even when the latter is present at a 3.3-fold higher concentration. Moreover, this ignores the sometimes greater effect of darkness on nitrate uptake (e.g. Hanisak \& Harlin 1978, Korb \& Gerard 2000). Consequently, the central issue with high safety factors for ammonium uptake is not the rate of uptake per se, but the reason for the surplus capacity. What are the ecological benefits to seaweeds of possessing a high surplus capacity for ammonium uptake?

In contrast to nitrate uptake, high safety factors for ammonium uptake suggest that the concentration of ammonium in the vicinity of a seaweed is unpredictable and that measured concentrations of ammonium in seawater do not account for spatial and temporal heterogeneity. A similar relationship between variable loads and high safety factors has been advanced for animal systems (Alexander 1981, Diamond 2002). With a high value for the safety factor, the relationship between the rate of uptake and nutrient concentration is closer to first-order. For ammonium uptake, increasing the ambient ammonium concentration from 1.5 to $3 \mu \mathrm{M}$ gives a median $84 \%$ (range $=34$ to $100 \%$ ) increase in the rate of uptake for seaweeds. Moreover, the limited amount of data suggests that ammonium assimilation will also have a high safety factor. Values (assuming a maximum external ammonium concentration of $1.5 \mu \mathrm{M}$ ) for Enteromorpha sp. and Osmundaria colensoi are 13 and 28, respectively (Taylor \& Rees 1999). One instance where unpredictable increases in ammonium concentration are likely to occur is excretion by animals associated with seaweeds.

Associations between seaweeds and animals involve both sessile and mobile animals. Ammonium is usually the major excretion product in these animals and evidence for uptake of this ammonium by seaweeds that are associated with the animal has been documented, together with the ecological role of this nutritional association (Carpenter 1990). Such nutritional associations with sessile animals include barnacles (Williamson \& Rees 1994) and bryozoans (Hurd et al. 1994, 2000). Nutritional associations involving mobile animals include sea urchins (Williams \& Carpenter 1988), small mobile invertebrates (Taylor \& Rees 1998), limpets (Plagányi \& Branch 2000) and fish (Meyer et al. 1983, Bray et al. 1986). These associations are likely to be of particular significance if they involve animals that feed on phytoplankton or other nitrogen-rich diets.

Another potential source of ammonium for seaweeds is sediments (Lavery \& McComb 1991, Krause-Jensen 
et al. 1996, Larned \& Stimson 1996, Sundbäck et al. 2003). For example, Caulerpa cupressoides is capable of taking up ammonium from sediments through its rhizoids (Williams 1984), with both rhizoids (Williams 1984) and whole plants (Williams \& Fisher 1985) having high $K_{\mathrm{m}}$ values for ammonium uptake. The high $K_{\mathrm{m}}$ values presumably reflect either the high (Williams \& Fisher 1985) or variable (Williams et al. 1985) ammonium concentrations present in the sediments. Most temperate seaweeds are attached to rocky substrates and the benthic boundary layer may limit access to sediment ammonium (Raven 1981, Hanisak 1983, MacFarlane \& Raven 1990). However, storms and animals may disturb sediments that are adjacent to seaweeds and cause temporally unpredictable, local increases in ammonium concentration that are accessible to seaweeds. With increased anthropogenic nitrogen loadings in estuaries and coastal waters (Morand \& Briand 1996, Valiela et al. 1997, Schramm 1999), seaweeds with high safety factors for nutrient uptake have a greater potential to take advantage of these increased nutrient concentrations than seaweeds with low safety factors. The problem will potentially be far greater if ammonium is the major constituent of anthropogenic nitrogen loadings.

The ratio $V_{\text {max }}: K_{\mathrm{m}}$ has been used as a measure of uptake capacities at low concentrations (Healey 1980, Duke et al. 1989). In essence it is a measure of the efficiency of uptake. The $V_{\max }: K_{\mathrm{m}}$ ratio tended to be greater for ammonium uptake than it was for either nitrate or phosphate uptake. Moreover, the relationships between nitrate and ammonium uptake at the maximum concentrations likely to be encountered in nature (5 and $1.5 \mu \mathrm{M}$, respectively) and the $\mathrm{SA}: V$ ratio were virtually identical. Both these lines of evidence suggest that uptake of ammonium is more efficient than that of nitrate. Though the $V_{\text {max }}: K_{\mathrm{m}}$ ratio does not provide any indication of the marked surplus capacity associated with ammonium uptake in seaweeds, it should be emphasized that this surplus capacity does not compromise the high and efficient rates of ammonium uptake at low external concentrations.

Concentrations of ammonium may vary both temporally (Ramus \& Venable 1987) and spatially (Eppley et al. 1979). For single-celled organisms such as phytoplankton, their small size means that the cell will be either entirely in or out of a patch of ammonium. In essence the probability is binary. If the cell is nitrogen deprived, covering the entire surface of the cell with high-affinity transporters would allow the cell to take maximum advantage of the elevated concentration of ammonium within the patch. However, most seaweeds are large plants relative to the size of most ammoniumexcreting animals, and any patch of elevated ammonium would only cover a small proportion of the plant surface area. In addition, it would be impossible for the plant to predict which part of its surface will be in contact with the patch. The most effective way of overcoming this problem is to ensure that a doubling in concentration at a given portion of the surface results in a close to doubling of the rate of uptake, i.e. to possess a high safety factor for uptake and assimilation.

Acknowledgements. I am grateful to B. C. Dobson for nutrient analyses and to A. D. M. Glass, C. L. Hurd, R. B. Taylor and 4 anonymous reviewers for their constructive comments on earlier drafts of this manuscript.

\section{LITERATURE CITED}

Alexander RM (1981) Factors of safety in the structure of animals. Sci Prog Oxford 67:109-130

Atkinson MJ, Smith SV (1983) C:N:P ratios of benthic plants. Limnol Oceanogr 28:568-574

Barr NG, Rees TAV (2003) Nitrogen status and metabolism in the green seaweed Enteromorpha intestinalis: an examination of three natural populations. Mar Ecol Prog Ser 249:133-144

Bird KT, Hanisak MD, Ryther J (1981) Chemical quality and production of agars extracted from Gracilaria tikvahiae grown in different nitrogen enrichment conditions. Bot Mar 24:441-444

Borum J, Sand-Jensen K (1996) Is total primary production in shallow coastal marine waters stimulated by nitrogen loading? Oikos 76:406-410

Bray RN, Purcell LJ, Miller AC (1986) Ammonium excretions in a temperate reef community by a planktiverous fish, Chromis puctipinnis (Pomencentridae), and potential uptake by young giant kelp, Macrocystis pyrifera (Laminariales). Mar Biol 90:327-334

Brown MT, Nyman MA, Keogh JA, Chin NKM (1997) Seasonal growth of the giant kelp Macrocystis pyrifera in New Zealand. Mar Biol 129:417-424

Campbell S (2001) Ammonium requirements of fast-growing ephemeral macroalgae in a nutrient-enriched marine embayment (Port Phillip Bay, Australia). Mar Ecol Prog Ser 209:99-107

Carpenter RC (1990) Competition among marine macroalgae: a physiological perspective. J Phycol 26:6-12

Cembella A, Antia NJ, Harrison PJ (1984) The utilization of inorganic and organic phosphorus compounds as nutrients by eukaryotic microalgae: a multidisciplinary perspective. CRC Crit Rev Microbiol 10:317-391

Chapman ARO, Craigie JS (1977) Seasonal growth in Laminaria longicruris: relations with dissolved inorganic nutrients and internal reserves of nitrogen. Mar Biol 40: 197-205

Charpy-Roubaud C, Sournia A (1990) The comparative estimation of phytoplanktonic, microphytobenthic and macrophytobenthic primary production in the oceans. Mar Microb Food Webs 4:31-57

Cloern JE (2001) Our evolving conceptual model of the coastal eutrophication problem. Mar Ecol Prog Ser 210: 223-253

Cohen JE, Small C, Mellinger A, Gallup J, Sachs J (1997) Estimates of coastal populations. Science 278:1211-1212

Diamond JM (1998) Evolution of biological safety factors: a cost/benefit analysis. In: Weibel ER, Taylor CR, Bolis L (eds) Principles of animal design: the optimization and 
symmorphosis debate. Cambridge University Press, Cambridge, p 21-27

Diamond J (2002) Quantitative evolutionary design. J Physiol (Lond) 542:337-345

Duarte CM (1992) Nutrient concentration of aquatic plants: patterns across species. Limnol Oceanogr 37:882-889

Duke CS, Litaker W, Ramus J (1989) Effects of temperature, nitrogen supply, and tissue nitrogen on ammonium uptake rates of the chlorophyte seaweeds Ulva curvata and Codium decorticatum. J Phycol 25:113-120

Eppley RW, Renger EH, Harrison WG, Cullen JJ (1979) Ammonium distribution in southern California coastal waters and its role in the growth of phytoplankton. Limnol Oceanogr 24:495-509

Gagne JA, Mann KH, Chapman ARO (1982) Seasonal patterns of growth and storage in Laminaria longicruris in relation to differing patterns of availability of nitrogen in the water. Mar Biol 69:91-101

Hanisak MD (1983) The nitrogen relationships of marine macroalgae. In: Carpenter EJ, Capone DG (eds) Nitrogen in the marine environment. Academic Press, New York, p 699-730

Hanisak MD, Harlin MM (1978) Uptake of inorganic nitrogen by Codium fragile subsp. tomentosoides (Chlorophyta). J Phycol 14:450-454

Healey FP (1980) Slope of the Monod equation as an indicator of advantage in nutrient competition. Microbiol Ecol 5: 281-286

Hein M, Pedersen MF, Sand-Jensen K (1995) Size-dependent nitrogen uptake in micro- and macroalgae. Mar Ecol Prog Ser 118:247-253

Hurd CL, Durante KM, Chia FS, Harrison PJ (1994) Effect of bryozoan colonization on inorganic nitrogen acquisition by the kelps Agarum fimbriatum and Macrocystis integrifolia. Mar Biol 121:167-173

Hurd CL, Durante KM, Harrison PJ (2000) Influence of bryozoan colonization on the physiology of the kelp Macrocystis integrifolia (Laminariales, Phaeophyta) from nitrogenrich and -poor sites in Barkley Sound, British Columbia, Canada. Phycologia 39:435-440

Korb RE, Gerard VA (2000) Nitrogen assimilation characteristics of polar seaweeds from differing nutrient environments. Mar Ecol Prog Ser 198:83-92

Koroleff F (1983a) Determination of phosphorus. In: Grasshof K, Ehrhardt M, Kremling K (eds) Methods of seawater analysis. Verlag Chemie, Weinheim, p 125-139

Koroleff F (1983b) Determination of ammonia. In: Grasshof K, Ehrhardt M, Kremling K (eds) Methods of seawater analysis. Verlag Chemie, Weinheim, p 150-157

Krause-Jensen D, McGlathery K, Rysgaard S, Chritensen PB (1996) Production within dense mats of the filamentous macroalga Chaetomorpha linum in relation to light and nutrient availability. Mar Ecol Prog Ser 134:207-216

Lapointe BE, Duke CS (1984) Biochemical strategies for growth of Gracilaria tikvahiae (Rhodophyta) in relation to light intensity and nitrogen availability. J Phycol 20: 488-495

Lapointe BE, Littler MM, Littler DS (1992) Nutrient availability to marine macroalgae in siliclastic versus carbonaterich coastal waters. Estuaries 15:75-82

Larned ST, Stimson J (1996) Nitrogen-limited growth in the coral reef chlorophyte Dictyosphaeria cavernosa, and the effect of exposure to sediment-derived nitrogen on growth. Mar Ecol Prog Ser 145:95-108

Lavery PS, McComb AJ (1991) The nutritional eco-physiology of Chaetomorpha linum and Ulva rigida in Peel Inlet, Western Australia. Bot Mar 34:251-260
Leigh EG, Paine RT, Quinn JF, Suchanek TH (1987) Wave energy and intertidal productivity. Proc Natl Acad Sci USA 84:1314-1318

Lobban CS, Harrison PJ (1994) Seaweed ecology and physiology. Cambridge University Press, Cambridge

MacFarlane JJ, Raven JA (1990) C, N and P nutrition of Lemanea mamillosa Kütz. (Batrachospermales, Rhodophyta) in the Dighty Burn, Angus, U.K. Plant Cell Environ 13:1-13

McCarthy JJ, Goldman JC (1979) Nitrogenous nutrition of marine phytoplankton in nutrient depleted waters. Science 203:670-672

Meyer JL, Schultz ET, Helfman GS (1983) Fish schools: an asset to corals. Science 220:1047-1049

Morand P, Briand X (1996) Excessive growth of macroalgae: a symptom of environmental disturbance. Bot Mar 39: 491-516

Nielsen SL, Sand-Jensen K (1990) Allometric scaling of maximal photosynthetic growth rate to surface/volume ratio. Limnol Oceanogr 35:177-181

O'Brien MC, Wheeler PA (1987) Short term uptake of nutrients by Enteromorpha prolifera (Chlorophyceae). J Phycol 23:547-556

Parsons TR, Maita Y, Lalli CM (1984) A manual of chemical and biological methods for seawater analysis. Pergamon Press, Oxford

Phillips JC (2001) The nitrogen ecophysiology of intertidal seaweeds. PhD thesis, University of Otago, Dunedin

Plagányi EE, Branch GM (2000) Does the limpet Patella cochlear fertilize its own algal garden? Mar Ecol Prog Ser 194:113-122

Probyn TA, Chapman ARO (1983) Summer growth of Chordaria flagelliformis (O.F. Muell.) C. Ag.: physiological strategies in a nutrient stressed environment. J Exp Mar Biol Ecol 73:243-271

Ramus J, Venable M (1987) Temporal ammonium patchiness and growth rate in Codium and Ulva (Ulvophyceae). J Phycol 23:518-523

Raven JA (1981) Nutritional strategies of submerged benthic plants: the acquisition of $\mathrm{C}, \mathrm{N}$ and $\mathrm{P}$ by rhizophytes and haptophytes. New Phytol 88:1-30

Rico JM, Fernandez C (1996) Seasonal nitrogen metabolism in an intertidal population of Gelidium latifolium (Gelidiaceae, Rhodophyta). Eur J Phycol 31:149-155

Rosenberg G, Ramus J (1984) Uptake of inorganic nitrogen and seaweed surface area: volume ratio. Aquat Bot 19: $65-72$

Schaffelke B, Klumpp DW (1998) Nutrient-limited growth of the coral reef macroalga Sargassum baccularia and experimental growth enhancement by nutrient addition in continuous flow culture. Mar Ecol Prog Ser 164:199-211

Schramm W (1999) Factors influencing seaweed responses to eutrophication: some results from EU-project EUMAC. J Appl Phycol 11:69-78

Sharp JH (1983) The distributions of inorganic nitrogen and dissolved and particulate organic nitrogen in the sea. In: Carpenter EJ, Capone DG (eds) Nitrogen in the marine environment. Academic Press, New York, p 1-35

Smith SV (1981) Marine macrophytes as a global carbon sink. Science 211:838-840

Sokal RR, Rohlf FJ (1995) Biometry, 3rd edn. WH Freeman, New York

Sundbäck K, Miles A, Hulth S, Pihl L, Engström P, Selander E, Svenson A (2003) Importance of benthic nutrient regeneration during initiation of macroalgal blooms in shallow bays. Mar Ecol Prog Ser 246:115-126

Taylor MW, Rees TAV (1999) Kinetics of ammonium assimila- 
tion in two seaweeds, Enteromorpha sp. (Chlorophyceae) and Osmundaria colensoi (Rhodophyceae). J Phycol 35: 740-746

Taylor RB, Rees TAV (1998) Excretory products of mobile epifauna as a nitrogen source for seaweeds. Limnol Oceanogr 43:600-606

Taylor RB, Peek JTA, Rees TAV (1998) Scaling of ammonium uptake by seaweeds to surface area: volume ratio: geographical variation and the role of uptake by passive diffusion. Mar Ecol Prog Ser 169:143-148

Valiela I, McClelland J, Hauxwell J, Behr PJ, Hersh D, Foreman K (1997) Macroalgal blooms in shallow estuaries: controls and ecophysiological and ecosystem consequences. Limnol Oceanogr 42:1105-1118

Wallentinus I (1984) Comparisons of nutrient uptake rates for Baltic macroalgae with different thallus morphologies.
Mar Biol 80:215-225

Williams SL (1984) Uptake of sediment ammonium and translocation in a marine green macroalga Caulerpa cupressoides. Limnol Oceanogr 29:374-379

Williams SL, Carpenter RC (1988) Nitrogen-limited primary productivity of coral reef algal turfs: potential contribution of ammonium-excreted by Diadema antillarum. Mar Ecol Prog Ser 47:145-152

Williams SL, Fisher TR (1985) Kinetics of nitrogen-15 labelled ammonium uptake by Caulerpa cupressoides (Chlorophyta). J Phycol 21:287-296

Williams SL, Yarish SM, Gill IP (1985) Ammonium distributions, production, and efflux from backreef sediments, St Croix, US Virgin Islands. Mar Ecol Prog Ser 24:57-64

Williamson JE, Rees TAV (1994) Nutritional interaction in an alga-barnacle association. Oecologia 99:16-20

Appendix 1. Summary of kinetic constants $\left(K_{\mathrm{m}}\right.$ and $\left.V_{\max }\right)$ for ammonium uptake, calculated rates of uptake at $1.5 \mu \mathrm{M}$ ammonium $\left(V_{1.5}\right)$, calculated safety factors assuming a maximum ambient ammonium concentration of $1.5 \mu \mathrm{M}[\mathrm{SF}(1.5)]$ and $V_{\max }: K_{\mathrm{m}}$ for ammonium uptake by seaweeds, together with location of each species. inf.: infinity

\begin{tabular}{|c|c|c|c|c|c|c|c|}
\hline Species & $K_{\mathrm{m}}(\mu \mathrm{M})$ & $V_{\max }$ & $V_{1.5}$ & $\mathrm{SF}(1.5)$ & $V_{\max }: K_{\mathrm{m}}$ & Location & Source \\
\hline \multicolumn{8}{|l|}{ Green } \\
\hline Acrosiphonia centralis & 19.07 & 115.21 & 8.40 & 13.71 & 6.04 & Baltic & Wallentinus (1984) \\
\hline Caulerpa cupressoides & 48.00 & 8.70 & 0.26 & 33.00 & 0.18 & Virgin Islands & Williams \& Fisher (1985) \\
\hline Chaetomorpha linum & inf. & & & inf. & & W. Australia & Lavery \& McComb (1991) \\
\hline Chaetomorpha linum & 13.00 & 132.00 & 13.66 & 9.67 & 10.15 & Denmark & Pedersen \& Borum (1997) \\
\hline Cladophora sp. & 20.70 & 130.00 & 8.78 & 14.80 & 6.28 & W. Australia & Gordon et al. (1981) \\
\hline Cladophora glomerata & 32.68 & 327.83 & 22.35 & 14.67 & 16.36 & Baltic & Wallentinus (1984) \\
\hline Cladophora serica & 13.00 & 122.00 & 12.62 & 9.67 & 9.38 & Denmark & Pedersen \& Borum (1997) \\
\hline Codium decorticatum & 12.00 & 13.43 & 1.49 & 9.00 & 1.12 & N. Carolina & Rosenberg \& Paerl (1981) \\
\hline $\begin{array}{l}\text { Codium fragile subsp. } \\
\text { tomentosoides }\end{array}$ & 1.61 & 23.66 & 11.49 & 2.06 & 15.02 & Rhode Island & Hanisak \& Harlin (1978) \\
\hline Codium fragile & 25.00 & 81.00 & 4.58 & 17.67 & 3.24 & Denmark & Pedersen \& Borum (1997) \\
\hline Enteromorpha sp. & 14.35 & 9.30 & 0.74 & 12.49 & 0.58 & Massachusetts & Fujita (1985) \\
\hline Enteromorpha ahlneriana & 16.64 & 409.40 & 33.85 & 12.09 & 24.60 & Baltic & Wallentinus (1984) \\
\hline Enteromorpha compressa & 24.00 & 36.79 & 2.16 & 17.00 & 1.53 & Baltic & Kautsky (1982) \\
\hline Enteromorpha intestinalis & inf. & & 6.57 & inf. & & New Zealand & Taylor et al. (1998) \\
\hline Enteromorpha prolifera & 8.53 & 138.40 & 19.47 & 7.11 & 15.92 & Oregon & O'Brien \& Wheeler (1987) \\
\hline Ulva sp. & 14.40 & 146.00 & 13.77 & 10.60 & 10.14 & S. Australia & Campbell (1999) \\
\hline Ulva sp. & inf. & & & inf. & & New Zealand & Taylor et al. (1998) \\
\hline Ulva curvata & 13.80 & & & 10.20 & & Connecticut & Duke et al. (1989) \\
\hline Ulva lactuca & 20.50 & 225.50 & 15.36 & 14.68 & 10.99 & Denmark & Pedersen \& Borum (1997) \\
\hline Ulva lactuca & 27.70 & 2.35 & 0.15 & 15.46 & 0.11 & Massachusetts & Fujita (1985) \\
\hline Ulva lactuca & 5.20 & 50.00 & 11.19 & 4.47 & 9.62 & Israel & Cohen \& Neori (1991) \\
\hline Ulva rigida & inf. & & & inf. & & W. Australia & Lavery \& McComb (1991) \\
\hline \multicolumn{8}{|l|}{ Red } \\
\hline Agardhiella subulata & 3.90 & 15.86 & 4.41 & 3.60 & 4.07 & Massachusetts & D'Elia \& DeBoer (1978) \\
\hline Apophlaea lyallii & 42.08 & 11.56 & 0.40 & 29.05 & 0.27 & New Zealand & Phillips (2001) \\
\hline Ceramium rubrum & 29.00 & 271.00 & 13.33 & 20.33 & 9.34 & Denmark & Pedersen \& Borum (1997) \\
\hline Ceramium rubrum & 3.60 & 25.20 & 7.41 & 3.40 & 7.00 & Massachusetts & DeBoer \& Whoriskey (1983) \\
\hline Ceramium tenuicorne & 16.93 & 143.43 & 15.66 & 9.16 & 12.59 & Baltic & Wallentinus (1984) \\
\hline Chondrus crispus & 35.50 & 61.71 & 2.50 & 24.67 & 1.74 & France & Amat \& Braud (1990) \\
\hline Furcellaria lumbricalis & 6.53 & 4.88 & 0.93 & 5.26 & 0.78 & Baltic & Wallentinus (1984) \\
\hline Gracilaria foliifera & 1.60 & 23.82 & 11.53 & 2.07 & 14.89 & Massachusetts & D'Elia \& DeBoer (1978) \\
\hline Gracilaria gracilis & 76.45 & 216.70 & 4.17 & 51.97 & 2.83 & South Africa & Smit (2002) \\
\hline Gracilaria pacifica & 10.00 & 30.00 & 3.91 & 7.67 & 3.00 & British Columbia & Thomas et al. (1987) \\
\hline Gracilaria tikvahiae & 24.83 & 2.67 & 0.16 & 16.90 & 0.11 & Massachusetts & Fujita (1985) \\
\hline Gracilariopsis lemaneiformis & 40.00 & 68.00 & 2.46 & 27.67 & 1.70 & N. Carolina & Vergara et al. (1995) \\
\hline Hypnea musciformis & 16.64 & 115.00 & 9.51 & 12.09 & 6.91 & Virgin Islands & Haines \& Wheeler (1978) \\
\hline Phyllophora truncata & 7.93 & 9.71 & 1.54 & 6.29 & 1.22 & Baltic & Wallentinus (1984) \\
\hline Polysiphonia decipiens & 2.60 & 57.40 & 21.00 & 2.73 & 22.08 & Melbourne & Campbell (1999) \\
\hline Porphyra sp. & inf. & & & inf. & & New Zealand & Taylor et al. (1998) \\
\hline Pterocladia capillacea & 45.00 & 65.00 & 2.10 & 31.00 & 1.44 & New Zealand & Taylor et al. (1998) \\
\hline Rhodomela confervoides & 23.86 & 38.07 & 2.25 & 16.91 & 1.60 & Baltic & Wallentinus (1984) \\
\hline Stictosiphonia arbuscula & inf & & 1.30 & $\inf$ & & New Zealand & Phillips (2001) \\
\hline
\end{tabular}


Appendix 1 (continued)

\begin{tabular}{|c|c|c|c|c|c|c|c|}
\hline Species & $K_{\mathrm{m}}(\mu \mathrm{M})$ & $V_{\max }$ & $V_{1.5}$ & $\mathrm{SF}(1.5)$ & $V_{\max }: K_{\mathrm{m}}$ & Location & Source \\
\hline \multicolumn{8}{|l|}{ Brown } \\
\hline Chorda filum & 3.44 & 23.64 & 7.18 & 3.29 & 6.87 & Baltic & Wallentinus (1984) \\
\hline Chordaria flagelliformis & 4.35 & 61.95 & 13.63 & 4.54 & 18.48 & Nova Scotia & $\begin{array}{l}\text { Probyn \& Chapman (1982), } \\
\text { Rosenberg et al. (1984) }\end{array}$ \\
\hline Dictyosiphon foeniculaceus & 3.60 & 54.43 & 16.01 & 3.40 & 15.12 & Baltic & Wallentinus (1984) \\
\hline Ecklonia radiata & inf. & & & inf. & & W. Australia & Paling (1991) \\
\hline Ectocarpus siliculosus & 3.46 & 39.79 & 12.03 & 3.31 & 11.50 & Baltic & Wallentinus (1984) \\
\hline Elachista fucicola & 20.93 & 133.86 & 8.95 & 14.95 & 6.40 & Baltic & Wallentinus (1984) \\
\hline Eudesme virescens & 4.78 & 38.14 & 9.11 & 4.19 & 7.98 & Baltic & Wallentinus (1984) \\
\hline Fucus distichus & 4.00 & 60.00 & 16.36 & 3.67 & 15.00 & British Columbia & Thomas et al. (1985) \\
\hline Fucus distichus & 3.61 & 13.90 & 4.08 & 3.41 & 3.85 & Nova Scotia & Rosenberg et al. (1984) \\
\hline Fucus spiralis & 7.47 & 23.51 & 3.89 & 6.05 & 3.13 & Massachusetts & Topinka (1978) \\
\hline Fucus vesiculosus & 14.93 & 24.62 & 2.05 & 12.01 & 1.60 & Denmark & $\begin{array}{l}\text { Wallentinus (1984), } \\
\text { Pedersen \& Borum (1997) }\end{array}$ \\
\hline Himantothallus grandifolius & 20.40 & & & 14.60 & & Antarctic & Korb \& Gerard (2000) \\
\hline Hincksia sordida & 39.70 & 802.00 & 29.20 & 27.47 & 20.20 & Melbourne & Campbell (1999) \\
\hline Laminaria abyssalis & 4.60 & 2.00 & 0.49 & 4.07 & 0.43 & Brazil & $\begin{array}{l}\text { Braga \& Yoneshigue- } \\
\text { Valentin (1996) }\end{array}$ \\
\hline Laminaria groenlandica & inf. & & 0.27 & inf. & & British Columbia & Harrison et al. (1986) \\
\hline Laminaria solidungula & 12.70 & & & 9.47 & & Canadian Arctic & Korb \& Gerard (2000) \\
\hline Macrocystis pyrifera & 4.85 & 20.00 & 4.41 & 4.54 & 3.77 & S. California & $\begin{array}{l}\text { Haines \& Wheeler (1978), } \\
\text { Wheeler (1979) }\end{array}$ \\
\hline Pilayella littoralis & 3.57 & 35.86 & 11.10 & 3.23 & 11.23 & Baltic & Wallentinus (1984) \\
\hline Sargassum baccularia & 4.81 & 13.02 & 3.10 & 4.21 & 2.71 & Great Barrier Reef & Schaffelke \& Klumpp (1998) \\
\hline Scytosiphon lomentaria & 3.90 & 69.07 & 19.19 & 3.60 & 17.71 & Baltic & Wallentinus (1984) \\
\hline Scytothamnus australis & 42.80 & 76.24 & 2.58 & 29.53 & 1.78 & New Zealand & Phillips (2001) \\
\hline Undaria pinnatifida & 19.75 & 119.50 & 16.09 & 7.43 & 14.11 & S. Australia & Campbell (1999) \\
\hline Xiphophora chondrophylla & inf. & & 0.12 & inf. & & New Zealand & Taylor et al. (1998) \\
\hline Xiphophora gladiata & 36.69 & 8.72 & 0.34 & 25.46 & 0.24 & New Zealand & Phillips (2001) \\
\hline
\end{tabular}

Appendix 2. Summary of kinetic constants $\left(K_{\mathrm{m}}\right.$ and $\left.V_{\max }\right)$ for nitrate uptake, calculated rates of uptake at $5 \mu \mathrm{M}$ nitrate $\left(V_{5}\right)$, calculated safety factors assuming a maximum ambient nitrate concentration of $5 \mu \mathrm{M}[\mathrm{SF}(5)]$ and $V_{\text {max }}: K_{\mathrm{m}}$ for nitrate uptake by seaweeds, together with location of each species

\begin{tabular}{|c|c|c|c|c|c|c|c|}
\hline Species & $K_{\mathrm{m}}(\mu \mathrm{M})$ & $V_{\max }$ & $V_{5}$ & $\mathrm{SF}(5)$ & $V_{\max }: K_{\mathrm{m}}$ & Location & Source \\
\hline \multicolumn{8}{|l|}{ Green } \\
\hline Chaetomorpha linum & inf. & & & inf. & & W. Australia & Lavery \& McComb (1991) \\
\hline Chaetomorpha linum & 3.00 & 30.00 & 18.75 & 1.60 & 10.00 & Denmark & Pedersen \& Borum (1997) \\
\hline Cladophora glomerata & 5.27 & 115.72 & 56.54 & 2.05 & 40.18 & Baltic & Wallentinus (1984) \\
\hline Cladophora serica & 5.00 & 17.00 & 8.50 & 2.00 & 3.40 & Denmark & Pedersen \& Borum (1997) \\
\hline $\begin{array}{l}\text { Codium fragile subsp. } \\
\text { tomentosoides }\end{array}$ & 4.28 & 6.83 & 3.55 & 1.92 & 2.00 & Rhode Island & Hanisak \& Harlin (1978) \\
\hline Codium fragile & 5.00 & 9.00 & 4.50 & 2.00 & 1.80 & Denmark & Pedersen \& Borum (1997) \\
\hline Enteromorpha sp. & 16.60 & 129.40 & 29.95 & 4.32 & 7.80 & Nova Scotia & Harlin (1978) \\
\hline Enteromorpha ahlneriana & 1.73 & 27.80 & 20.65 & 1.35 & 16.07 & Baltic & Wallentinus (1984) \\
\hline Enteromorpha intestinalis & 17.22 & 64.65 & 14.55 & 4.44 & 3.75 & New Zealand & Rees et al. (unpubl.) \\
\hline Enteromorpha prolifera & 7.81 & 122.20 & 48.87 & 2.50 & 22.67 & Oregon & O'Brien \& Wheeler (1987) \\
\hline Ulva lactuca & 5.00 & 20.00 & 10.00 & 2.00 & 4.00 & Denmark & Pedersen \& Borum (1997) \\
\hline Ulva rigida & 25.68 & 71.89 & 11.72 & 6.14 & 2.80 & W. Australia & Lavery \& McComb (1991) \\
\hline \multicolumn{8}{|l|}{ Red } \\
\hline Agardhiella subulata & 2.40 & 11.67 & 7.89 & 1.48 & 4.86 & Massachusetts & D'Elia \& DeBoer (1978) \\
\hline Apophlaea lyallii & 9.26 & 2.19 & 0.77 & 2.85 & 0.24 & New Zealand & Phillips (2001) \\
\hline Ceramium rubrum & 7.57 & 5.99 & 2.38 & 2.51 & 0.79 & Baltic & Wallentinus (1984) \\
\hline Ceramium tenuicorne & 3.91 & 18.67 & 10.69 & 1.75 & 5.56 & Baltic & Wallentinus (1984) \\
\hline Furcellaria lumbricalis & 15.29 & 3.19 & 0.63 & 5.02 & 0.19 & Baltic & Wallentinus (1984) \\
\hline Gracilaria foliifera & 2.48 & 9.71 & 6.49 & 1.50 & 3.92 & Massachusetts & D'Elia \& DeBoer (1978) \\
\hline Gracilaria gracilis & 5.80 & 26.28 & 12.16 & 2.16 & 4.53 & South Africa & Smit (2002) \\
\hline Gracilaria pacifica & 6.00 & 4.00 & 1.82 & 2.20 & 0.67 & Vancouver & Thomas et al. (1987) \\
\hline Hypnea musciformis & 4.90 & 28.50 & 14.39 & 1.98 & 5.82 & Virgin Islands & Haines \& Wheeler (1978) \\
\hline Phyllophora truncata & 9.21 & 1.69 & 0.60 & 2.84 & 0.18 & Baltic & Wallentinus (1984) \\
\hline Pterocladia capillacea & 14.19 & 14.20 & 3.70 & 3.84 & 1.00 & New Zealand & Rees et al. (unpubl.) \\
\hline Rhodomela confervoides & 4.46 & 12.14 & 6.42 & 1.89 & 2.72 & Baltic & Wallentinus (1984) \\
\hline Stictosiphonia arbuscula & 18.68 & 16.21 & 4.21 & 3.85 & 1.43 & New Zealand & Phillips (2001) \\
\hline
\end{tabular}


Appendix 2 (continued)

\begin{tabular}{|c|c|c|c|c|c|c|c|}
\hline Species & $K_{\mathrm{m}}(\mu \mathrm{M})$ & $V_{\max }$ & $V_{5}$ & $\mathrm{SF}(5)$ & $V_{\max }: K_{\mathrm{m}}$ & Location & Source \\
\hline \multicolumn{8}{|l|}{ Brown } \\
\hline Chorda filum & 0.60 & 6.63 & 5.92 & 1.12 & 11.05 & Baltic & Wallentinus (1984) \\
\hline Chordaria flagelliformis & 5.10 & 5.93 & 2.94 & 2.02 & 1.16 & Nova Scotia & Probyn (1984) \\
\hline Dictyosiphon foeniculaceus & 4.34 & 63.79 & 34.15 & 1.87 & 14.70 & Baltic & Wallentinus (1984) \\
\hline Elachista fucicola & 1.94 & 17.57 & 12.66 & 1.39 & 9.06 & Baltic & Wallentinus (1984) \\
\hline Eudesme virescens & 2.23 & 10.29 & 7.11 & 1.45 & 4.61 & Baltic & Wallentinus (1984) \\
\hline Fucus distichus & 3.50 & 20.00 & 11.76 & 1.70 & 5.71 & British Columbia & Thomas et al. (1985) \\
\hline Fucus spiralis & 6.70 & 17.56 & 7.47 & 2.35 & 2.62 & Massachusetts & Topinka (1978) \\
\hline Fucus vesiculosus & 24.69 & 9.29 & 2.08 & 4.47 & 0.65 & Denmark & $\begin{array}{l}\text { Wallentinus (1984), } \\
\text { Pedersen \& Borum (1997) }\end{array}$ \\
\hline Himantothallus grandifolius & 12.80 & & & 3.56 & & Antarctic & Korb \& Gerard (2000) \\
\hline Kjellmaniella crassifolia & 4.48 & & & 1.90 & & Japan & Ozaki et al. (2001) \\
\hline Laminaria abyssalis & 14.00 & 5.00 & 1.32 & 3.80 & 0.36 & Brazil & $\begin{array}{l}\text { Braga \& Yoneshigue- } \\
\text { Valentin (1996) }\end{array}$ \\
\hline Laminaria japonica & 2.56 & & & 1.51 & & Japan & Ozaki et al. (2001) \\
\hline Laminaria longicruris & 4.67 & 9.66 & 4.97 & 1.94 & 2.11 & Nova Scotia & $\begin{array}{l}\text { Harlin \& Craigie (1978), } \\
\text { Espinoza \& Chapman (1983 }\end{array}$ \\
\hline Laminaria groenlandica & inf. & & 0.85 & inf. & & British Columbia & Harrison et al. (1986) \\
\hline Laminaria solidungula & 35.00 & & & 8.00 & & Canadian Arctic & Korb \& Gerard (2000) \\
\hline Macrocystis pyrifera & 6.82 & 13.79 & 5.14 & 2.69 & 1.64 & S. California & Haines \& Wheeler (1978) \\
\hline Pilayella littoralis & 8.64 & 51.32 & 18.82 & 2.73 & 7.05 & Baltic & Wallentinus (1984) \\
\hline Scytosiphon lomentaria & 6.92 & 59.36 & 24.90 & 2.38 & 8.58 & Baltic & Wallentinus (1984) \\
\hline Scytothamnus australis & 17.74 & 10.26 & 2.26 & 4.55 & 0.58 & New Zealand & Phillips (2001) \\
\hline Xiphophora chondrophylla & 9.99 & 2.92 & 0.97 & 3.00 & 0.29 & New Zealand & Rees et al. (unpubl.) \\
\hline Xiphophora gladiata & 20.97 & 5.19 & 1.00 & 5.19 & 0.25 & New Zealand & Phillips (2001) \\
\hline
\end{tabular}

Appendix 3. Summary of kinetic constants $\left(K_{\mathrm{m}}\right.$ and $\left.V_{\max }\right)$ for phosphate uptake, calculated rates of uptake at $1 \mu \mathrm{M}$ phosphate $\left(V_{1}\right)$, calculated safety factors assuming a maximum ambient phosphate concentration of $1 \mu \mathrm{M}[\mathrm{SF}(1)]$ and $V_{\text {max }}: K_{\mathrm{m}}$ for phosphate uptake by seaweeds, together with location of each species

\begin{tabular}{|c|c|c|c|c|c|c|c|}
\hline Species & $K_{\mathrm{m}}(\mu \mathrm{M})$ & $V_{\max }$ & $V_{1}$ & $\mathrm{SF}(1)$ & $V_{\max }: K_{\mathrm{m}}$ & Location & Source \\
\hline \multicolumn{8}{|l|}{ Green } \\
\hline Acrosiphonia centralis & 1.43 & 3.32 & 1.37 & 2.43 & 2.33 & Baltic & Wallentinus (1984) \\
\hline Chaetomorpha linum & 10.35 & 21.52 & 1.90 & 11.35 & 2.08 & W. Australia & Lavery \& McComb (1991) \\
\hline Cladophora sp. & 0.48 & 3.61 & 2.43 & 1.48 & 7.47 & W. Australia & Gordon et al. (1981) \\
\hline Cladophora glomerata & 0.33 & 3.06 & 2.30 & 1.33 & 9.29 & Baltic & Wallentinus (1984) \\
\hline Enteromorpha ahlneriana & 1.51 & 4.59 & 1.48 & 3.09 & 4.65 & Baltic & Wallentinus (1984) \\
\hline Enteromorpha compressa & 1.00 & 1.90 & 0.95 & 2.00 & 1.90 & Baltic & Kautsky (1982) \\
\hline Monostroma grevillei & 2.71 & 2.79 & 0.75 & 3.71 & 1.03 & Baltic & Wallentinus (1984) \\
\hline Ulva rigida & 3.65 & 8.77 & 1.89 & 4.65 & 2.40 & W. Australia & Lavery \& McComb (1991) \\
\hline \multicolumn{8}{|l|}{ Red } \\
\hline Agardhiella subulata & 0.40 & 0.47 & 0.34 & 1.40 & 1.18 & Massachusetts & DeBoer (1981) \\
\hline Ceramium tenuicorne & 1.00 & 0.78 & 0.51 & 1.55 & 1.56 & Baltic & Wallentinus (1984) \\
\hline Furcellaria lumbricalis & 2.97 & 0.13 & 0.03 & 4.00 & 0.64 & Baltic & Wallentinus (1984) \\
\hline Phyllophora truncata & 0.37 & 0.12 & 0.08 & 1.37 & 0.32 & Baltic & Wallentinus (1984) \\
\hline Rhodomela confervoides & 1.03 & 0.64 & 0.31 & 2.03 & 0.62 & Baltic & Wallentinus (1984) \\
\hline \multicolumn{8}{|l|}{ Brown } \\
\hline Ascophyllum nodosum & 1.22 & 0.07 & 0.03 & 2.20 & 0.07 & Ireland & Hurd \& Dring (1990) \\
\hline Chorda filum & 0.62 & 1.38 & 0.85 & 1.62 & 2.22 & Baltic & Wallentinus (1984) \\
\hline Dictyosiphon foeniculaceus & 2.12 & 11.13 & 3.56 & 3.12 & 5.24 & Baltic & Wallentinus (1984) \\
\hline Ectocarpus siliculosus & 1.22 & 0.75 & 0.34 & 2.22 & 0.61 & Baltic & Wallentinus (1984) \\
\hline Eudesme virescens & 0.67 & 3.55 & 2.12 & 1.67 & 5.26 & Baltic & Wallentinus (1984) \\
\hline Fucus serratus & 6.95 & 0.39 & 0.05 & 7.17 & 0.07 & Ireland & $\begin{array}{l}\text { Hurd \& Dring (1990), } \\
\text { Hurd et al. (1993) }\end{array}$ \\
\hline Fucus spiralis & 5.34 & 0.75 & 0.14 & 5.39 & 0.18 & Ireland & $\begin{array}{l}\text { Hurd \& Dring (1990), } \\
\text { Hurd et al. (1993) }\end{array}$ \\
\hline Fucus vesiculosus & 7.58 & 0.38 & 0.06 & 6.58 & 0.07 & Ireland & Hurd \& Dring (1990) \\
\hline Fucus vesiculosus & 11.17 & 1.05 & 0.15 & 6.95 & 0.21 & Baltic & Wallentinus (1984) \\
\hline Kjellmaniella crassifolia & 0.31 & & & 1.31 & & Japan & Ozaki et al. (2001) \\
\hline Laminaria abyssalis & 2.21 & 0.83 & 0.26 & 3.21 & 0.38 & Brazil & $\begin{array}{l}\text { Braga \& Yoneshigue- } \\
\text { Valentin (1996) }\end{array}$ \\
\hline Laminaria japonica & 0.14 & & & 1.14 & & Japan & Ozaki et al. (2001) \\
\hline Macrocystis pyrifera & 3.51 & & & 4.51 & & California & Manley (1985) \\
\hline Pelvetia canaliculata & 5.96 & 0.36 & 0.05 & 6.94 & 0.06 & Ireland & Hurd \& Dring (1990) \\
\hline Pilayella littoralis & 3.07 & 4.89 & 1.22 & 3.99 & 1.71 & Baltic & Wallentinus (1984) \\
\hline Sargassum baccularia & 0.26 & 0.43 & 0.34 & 1.26 & 1.65 & Great Barrier Reef & Schaffelke \& Klumpp (1998) \\
\hline Scytosiphon lomentaria & 0.77 & 6.58 & 3.71 & 1.77 & 8.50 & Baltic & Wallentinus (1984) \\
\hline
\end{tabular}


Appendix 4. Summary of surface area:volume (SA:V) ratios for seaweeds

\begin{tabular}{|c|c|c|}
\hline Species & $\mathrm{SA}: V$ & Source \\
\hline \multicolumn{3}{|l|}{ Green } \\
\hline Codium fragile & 8.9 & Rosenberg \& Ramus (1984) \\
\hline Chaetomorpha linum & 237 & Nielsen \& Sand-Jensen (1990) \\
\hline Enteromorpha intestinalis & 315 & Taylor et al. (1998) \\
\hline Ulva lactuca & 400 & Odum et al. (1958) \\
\hline Enteromorpha ahlneriana & 529 & Hein et al. (1995) \\
\hline Enteromorpha prolifera & 529 & Hein et al. (1995) \\
\hline Cladophora glomerata & 569 & Hein et al. (1995) \\
\hline Cladophora serica & 645 & Nielsen \& Sand-Jensen (1990) \\
\hline \multicolumn{3}{|l|}{ Red } \\
\hline Phyllophora truncata & 8.9 & Hein et al. (1995) \\
\hline Apophlaea lyallii & 14.9 & Phillips (2001) \\
\hline Furcellaria lumbricalis & 20.5 & Hein et al. (1995) \\
\hline Gracilaria foliifera & 30 & Hein et al. (1995) \\
\hline Gracilaria pacifica & 30 & Hein et al. (1995) \\
\hline Stictosiphonia arbuscula & 41.59 & Phillips (2001) \\
\hline Pterocladia capillacea & 80 & Taylor et al. (1998) \\
\hline Ceramium tenuicorne & 191 & Hein et al. (1995) \\
\hline Rhodomela confervoides & 207.9 & Hein et al. (1995) \\
\hline \multicolumn{3}{|l|}{ Brown } \\
\hline Xiphophora gladiata & 15.6 & Phillips (2001) \\
\hline Chorda filum & 17 & Odum et al. (1958) \\
\hline Scytothamnus australis & 19.2 & Phillips (2001) \\
\hline Xiphophora chondrophylla & 21 & Taylor et al. (1998) \\
\hline Fucus distichus & 30 & Hein et al. (1995) \\
\hline Fucus vesiculosus & 33.7 & Odum et al. (1958), Nielsen \& Sand-Jensen (1990) \\
\hline Fucus spiralis & 34 & Nielsen \& Sand-Jensen (1990) \\
\hline Chordaria flagelliformis & 100 & Hein et al. (1995) \\
\hline Dictyosiphon foeniculaceus & 408.5 & Hein et al. (1995) \\
\hline Elachista fucicola & 1042.3 & Hein et al. (1995) \\
\hline Pilayella littoralis & 1694 & Hein et al. (1995) \\
\hline
\end{tabular}

Appendix 5. Summary of $K_{\mathrm{m}}$ for ammonium uptake and calculated safety factors assuming a maximum ambient ammonium concentration of $1.5 \mu \mathrm{M}$ [SF(1.5)] for coastal clones of phytoplankton

\begin{tabular}{|lccl|}
\hline Species & $K_{\mathrm{m}}(\mu \mathrm{M})$ & $\mathrm{SF}(1.5)$ & \\
\hline Asterionella japonica & 1.05 & 1.70 & Source \\
Chaetoceros debilis & 0.50 & 1.33 & Conway et al. (1969) \\
Coscinodiscus lineatus & 2.00 & 2.33 & Eppley et al. (1969) \\
Coscinodiscus wailesii & 4.90 & 4.27 & Eppley et al. (1969) \\
Ditylum brightwellii & 1.10 & 1.73 & Eppley et al. (1969) \\
Dunaliella tertiolecta & 0.10 & 1.07 & Eppley et al. (1969) \\
Gonyaulax polyedra & 5.50 & 4.67 & Eppley et al. (1969) \\
Gymnodinium splendens & 1.10 & 1.73 & Eppley et al. (1969) \\
Leptocylindricus danicus & 1.60 & 2.07 & Eppley et al. (1969) \\
Monochrysis lutheri & 0.50 & 1.33 & Eppley et al. (1969) \\
Phaeodactylum tricornutum & 1.47 & 1.98 & Grant (2002) \\
Rhizosolenia robusta & 7.45 & 5.97 & Eppley et al. (1969) \\
Rhizosolenia stolterfothii & 0.50 & 1.33 & Eppley et al. (1969) \\
Skeletonema costatum & 1.23 & 1.82 & Conway et al. (1976), Conway \& Harrison (1977) \\
Thalassiosira gravida & 0.50 & 1.33 & Conway \& Harrison (1977) \\
\hline
\end{tabular}




\section{LITERATURE CITED FOR APPENDICES}

Amat MA, Braud JP (1990) Ammonium uptake by Chondrus crispus Stackhouse (Gigartinales, Rhodophyta) in culture. Hydrobiologia 204/205:467-471

Braga A, Yoneshigue-Valentin Y (1996) Nitrogen and phosphorus uptake by the Brazilian kelp Laminaria abyssalis (Phaeophyta) in culture. Hydrobiologia 326/327:445-450

Campbell SJ (1999) Uptake of ammonium by four species of macroalgae in Port Phillip Bay, Victoria, Australia. Mar Freshw Res 50:515-522

Cohen I, Neori A (1991) Ulva lactuca biofilters for marine fishpond effluents. I. Ammonia uptake kinetics and nitrogen content. Bot Mar 34:475-482

Conway HL, Harrison PJ (1977) Marine diatoms grown in chemostats under silicate or ammonium limitation. IV. Transient response of Chaetoceros debilis, Skeletonema costatum, and Thalassiosira gravida to a single addition of the limiting nutrient. Mar Biol 43:33-43

Conway HL, Harrison PJ, Davis CO (1976) Marine diatoms grown in chemostats under silicate or ammonium limitation. II. Transient response of Skeletonema costatum to a single addition of the limiting nutrient. Mar Biol 35:187-199

DeBoer JA (1981) Nutrients. In: Lobban CS, Wynne MJ (eds) The biology of seaweeds. Blackwell Scientific, Oxford, p 356-391

DeBoer JA, Whoriskey FG (1983) Production and role of hyaline hairs in Ceramium rubrum. Mar Biol 77:229-234

D'Elia CF, DeBoer JA (1978) Nutritional studies of two red algae. II. Kinetics of ammonium and nitrate uptake. J Phycol 14:266-272

Duke CS, Litaker W, Ramus J (1989) Effect of temperature on nitrogen-limited growth rate and chemical composition of Ulva curvata (Ulvales: Chlorophyta). Mar Biol 100, 143-150

Eppley RW, Rogers JN, McCarthy JJ (1969) Half-saturation constants for uptake of nitrate and ammonium by marine phytoplankton. Limnol Oceanogr 14:912-920

Espinoza J, Chapman ARO (1983) Ecotypic differentiation of Laminaria longicruris in relation to seawater nitrate concentrations. Mar Biol 74:213-218

Fujita RM (1985) The role of nitrogen status in regulating transient ammonium uptake and nitrogen storage by macroalgae. J Exp Mar Biol Ecol 92:283-301

Gordon DM, Birch PB, McComb AJ (1981) Effects of inorganic nitrogen on the growth of an estuarine Cladophora in culture. Bot Mar 24:93-106

Grant CM (2002) Characteristics of nitrogen- and iron-limited growth in the diatom Phaeodactylum tricornutum and in natural phytoplankton populations. PhD thesis, University of Auckland, Auckland

Haines KC, Wheeler PA (1978) Ammonium and nitrate uptake by the marine macrophytes Hypnea musciformis (Rhodophyta) and Macrocystis pyrifera (Phaeophyta). J Phycol 14:319-324

Hanisak MD, Harlin MM (1978) Uptake of inorganic nitrogen by Codium fragile spp. tomentosoides (Chlorophyta). J Phycol 14:450-454

Harlin MM (1978) Nitrate uptake by Enteromorpha spp. (Chlorophyceae): applications to aquaculture systems. Aquaculture 15:373-376

Harlin MM, Craigie JS (1978) Nitrate uptake by Laminaria longicruris (Phaeophyceae). J Phycol 14:464-467

Harrison PJ, Druehl LD, Lloyd KE, Thompson PA (1986) Nitrogen uptake kinetics in three year-classes of Laminaria groenlandica (Laminariales: Phaeophyta). Mar Biol 93:29-35
Hein M, Pedersen MF, Sand-Jensen K (1995) Size-dependent nitrogen uptake in micro- and macroalgae. Mar Ecol Prog Ser 118:247-253

Hurd CL, Dring MJ (1990) Phosphate uptake by intertidal algae in relation to zonation and season. Mar Biol 107: 281-289

Hurd CL, Galvin RS, Norton TA, Dring MJ (1993) Production of hyaline hairs by intertidal species of Fucus (Fucales) and their role in phosphate uptake. J Phycol 29:160-165

Kautsky L (1982) Primary production and uptake kinetics of ammonium and phosphate by Enteromorpha compressa in an ammonium sulfate industry outlet area. Aquat Bot 12:23-40

Korb RE, Gerard VA (2000) Nitrogen assimilation characteristics of polar seaweeds from differing nutrient environments. Mar Ecol Prog Ser 198:83-92

Lavery PS, McComb AJ (1991) The nutritional eco-physiology of Chaetomorpha linum and Ulva rigida in Peel Inlet, Western Australia. Bot Mar 34:251-260

Manley SL (1985) Phosphate uptake by blades of Macrocystis pyrifera (Phaeophyta). Bot Mar 28:237-244

Nielsen SL, Sand-Jensen K (1990) Allometric scaling of maximal photosynthetic growth rate to surface/volume ratio. Limnol Oceanogr 35:177-181

O'Brien MC Wheeler PA (1987) Short term uptake of nutrients by Enteromorpha prolifera (Chlorophyceae). J Phycol 23:547-556

Odum EP, Kuenzler EJ, Blunt SMX (1958) Uptake of $\mathrm{P}_{32}$ and primary productivity in marine benthic algae. Limnol Oceanogr 3:340-345

Ozaki A, Mizuta H, Yamamoto H (2001) Physiological differences between the nutrient uptakes of Kjellmaniella crassifolia and Laminaria japonica (Phaeophyceae). Fish Sci 67:415-419

Paling EI (1991) The relationship between nitrogen cycling and productivity in macroalgal stands and seagrass meadows. PhD thesis, University of Western Australia, Perth

Pedersen MF, Borum J (1997) Nutrient control of estuarine macroalgae: growth strategy and the balance between nitrogen requirements and uptake. Mar Ecol Prog Ser 161:155-163

Phillips JC (2001) The nitrogen ecophysiology of intertidal seaweeds. PhD thesis, University of Otago, Dunedin

Probyn TA (1984) Nitrate uptake by Chordaria flagelliformis (Phaeophyta). Bot Mar 27:271-275

Probyn TA, Chapman ARO (1982) Nitrogen uptake characteristics of Chordaria flagelliformis (Phaeophyta) in batch and continuous mode experiments. Mar Biol 71:129-133

Rosenberg G, Paerl HW (1981) Nitrogen fixation by bluegreen algae associated with the siphonous green seaweed Codium decorticatum: effects on ammonium uptake. Mar Biol 61:151-158

Rosenberg G, Ramus J (1984) Uptake of inorganic nitrogen and seaweed surface area: volume ratio. Aquat Bot 19: $65-72$

Rosenberg G, Probyn TA, Mann KH (1984) Nutrient uptake and growth kinetics in brown seaweeds: response to continuous and single additions of ammonium. J Exp Mar Biol Ecol 80:125-146

Schaffelke B, Klumpp DW (1998) Nutrient-limited growth of the coral reef macroalga Sargassum baccularia and experimental growth enhancement by nutrient addition in continuous flow culture. Mar Ecol Prog Ser 164:199-211

Smit AJ (2002) Nitrogen uptake by Gracilaria gracilis (Rhodophyta): adaptations to a temporally variable nitrogen environment. Bot Mar 45:196-209 
Taylor RB, Peek JTA, Rees TAV (1998) Scaling of ammonium uptake by seaweeds to surface area: volume ratio: geographical variation and the role of uptake by passive diffusion. Mar Ecol Prog Ser 169:143-148

Thomas TE, Harrison PJ, Taylor EB (1985) Nitrogen uptake and growth of the germlings and mature thalli of Fucus distichus. Mar Biol 84:267-274

Topinka JA (1978) Nitrogen uptake by Fucus spiralis (Phaeophyceae). J Phycol 14:241-247

Vergara JJ, Bird KT, Niell FX (1995) Nitrogen assimilation following $\mathrm{NH}_{4}^{+}$pulses in the red alga Gracilariopsis

Editorial responsibility: Otto Kinne (Editor),

Oldendorf/Luhe, Germany lemaneiformis: effect of C metabolism. Mar Ecol Prog Ser 122:253-263

Wallentinus I (1984) Comparisons of nutrient uptake rates for Baltic macroalgae with different thallus morphologies. Mar Biol 80:215-225

Wheeler PA (1979) Uptake of methylamine (an ammonium analogue) by Macrocystis pyrifera (Phaeophyta). J Phycol 15:12-17

Williams SL, Fisher TR (1985) Kinetics of nitrogen-15 labelled ammonium uptake by Caulerpa cupressoides (Chlorophyta). J Phycol 21:287-296

Submitted: December 3, 2002; Accepted: July 17, 2003

Proofs received from author(s): November 18, 2003 